\title{
The Party of Evil Genius in Orwell's 1984
}

\author{
Malek J. Zuraikat ${ }^{1} \&$ Haneen al-Nawasreh ${ }^{2}$ \\ ${ }^{1}$ Department of English, Yarmouk University. Corresponding author. \\ ORCID: 0000-0003-1948-2671. Email: m.zuraikat@yu.edu.jo \\ 2Independent Researcher, Jordan. Email: 2018300002@ses.yu.edu.jo
}

\begin{abstract}
This paper explores the strategies of Evil Genius for manipulating people's principles, thoughts, orientations, and ideologies in favor of promoting the logic of the party of Evil Genius, as found in Orwell's 1984 (1949). Relying on Descartes's definition of Evil Genius, we argue that the party in 1984 deploys the strategies of delusional propaganda, memory resetting, and doublethink to convince people of the significance of Big Brother for their peace and prosperity. The paper examines the party's approach towards Winston, who has always been suspicious of the party, contending that the party successfully toys with Winston's mental and emotional perspectives, thus leading him to view his own ego or rationale as his worst enemy. Such a reading is significant due to potential similarities between Winston's experience of victimization and people's feeling of being victimized by the party of Evil Genius in the postmodern society.
\end{abstract}

\section{Keywords}

Descartes, Evil Genius, George Orwell, 1984, postmodernism.

\section{Introduction}

George Orwell's 1984 tackles the hypothesis of Evil Genius that is incarnated in the leprechaun party and its representative O'Brien. It displays the role of Evil Genius as a timeless and placeless entity that obtains the power to transform the real world into illusions and the illusionary into real. The novel shows how Evil Genius examines people's senses and awareness of the external world trying to delude them to believe that the world of Evil Genius is the one that makes sense, a strategy that potentially causes people to suspect everything real. Introducing the people of Oceania as predominately dominated by an illusion created by a group of psychopaths who turn people's external world into a dystopian nightmare, the novel emphasizes that Evil Genius may emerge in form of a deceptive mindset of an evil person who uses his genius cunning to manipulate people and impact their perception of reality in favor of supporting the ideology and interests of the party of Evil Genius. This is evident in Orwell's 1984, where the party of Evil Genius deploys illusionary propaganda, memory resetting, and doublethink to create its own deceptive 
world, Oceania, and promote it among people. Accordingly, decoding the centrality of Oceania and its evil structure and ideology is inevitable to understanding 1984.

This paper contends that the party of Evil Genius in Orwell's narrative establishes a systemized place that has no past by adjusting all facts in accordance with the party's demonic plans and goals. For instance, the party works hard to provide the rebel of the wary mind, Winston Smith, with a blurred vision of everything and consequently deconstructs his perception as well as emotions and gets access to his ego. Such a demeanor of the party reflects its vision and consistent conspiracy against humans and their consciousness, which usually aims at viewing Big Brother as the ideal guardian of people's life, peace, prosperity, and dreams. To better understand this philosophy, it is necessary to state here that Evil Genius (known also as Evil Demon) is a concept that refers to "a person with an exceptional capacity for wrongdoing or malevolence" (Oxford English and Spanish Dictionary). Such a powerful, cunning, malicious, knowledgeable, deceitful, and marvelously creative figure intentionally misleads people and creates illusions, which eventually suspends their thoughts once they think of anything's reality. In Descartes: Meditations on First Philosophy: With Selections from the Objections and Replies, Rene Descartes (1996) explains the undeniable existence and perilous nature of such figure, emphasizing that Evil Genius of the "utmost power and cunning has employed all his energies in order to deceive [humans]" (p. 19). Evil Genius is a figure that manipulates people's minds and controls their experience of the external world.

Interestingly, Descartes associates the theory of Evil Genius with his Method of Doubt. In his Meditations on First Philosophy, Descartes contemplates that Evil Genius can be a being that resembles God in characteristics, but it is neither good nor perfect. He writes "I shall think that the sky, the air, the earth, colors, shapes, sounds, and all external things are merely the delusions of dreams which [Evil Genius] has devised to ensnare my judgment. I shall consider myself as not having hands or eyes, or flesh, or blood, or senses, but as falsely believing that I have all these things" (1996, p. 19). Descartes doubts all his beliefs regarding the establishment of "an absolute referential ground for truth and certainty" (qtd. in Dearey, 2014, p. 53). He believes that humans should have attentive minds that never accept false beliefs, a remark that clearly points to his philosophical principle: "I am thinking, therefore I exist" (Descartes, 1996, p. 68). Thus, Descartes recommends people to not doubt their senses and be always free from their previous beliefs and doubts that are based on their sensory knowledge, as beliefs and doubts are vulnerable to the manipulation of Evil Genius. To comprehend this Cartesian philosophy and its manifestations in Orwell's 1984 , the following subsection concisely reviews the related literature emphasizing how Descartes' Evil Genius functions as a finitude figure or force in people's life experience and perception of the outer world. 


\section{Literature Review}

The role of Evil Genius in influencing people's beliefs and manipulating their trust in mathematics and geometry, as evident in Orwell's 1984, has attracted the attention of several scholars. For example, O.K. Bouwsma (1949) mentions that "the Evil Genius is himself befuddled and that if we too exhaust some of our energies in sleuthing after the peculiarities in his diction, then we need not be deceived either" (p. 142). Richard Kennington (1971) mentions that "the texts of the Meditation by no means establish that the Evil Genius is omnipotent, but imply rather his finitude" (p. 441). Likewise, it is stated in Contemporary Perspective in the Philosophy of Language that Descartes' Evil Genius is different from Willard Quine's, which is limited and finitude and "bears no ill towards our beliefs about natural science. His deceit is limited to our views about language and thought" (French, Uehling Jr., and Wettstein, 1979, p. 278). Also, Kandace Lytle in her article "Seeing isn't Believing" notes that "Descartes never explains the Evil Genius' motivation for deceiving humankind but maintains that if we doubt the everyday world of solid objects, which is what the Evil Genius can manipulate, then truth lies in our ability to think" (Lytle, 2012, p. 88).

Considering this complexity of Evil Genius and the way it behaves against humans, Ronald Butler (1972) notices that "Evil Genius ... disappears with the affirmation of the cogito" (p. 123). This suggests that people can defeat the finitude figure of Evil Genius if they get aware of it/him, as evident in Shakespeare's Hamlet where Evil Genius is killed when discovered. J. M. Bernstein (2009) reads Hamlet arguing that "Claudius is the evil demon of Hamlet's world" (p. 84) who has disappeared when his evilness is recognized by others. This viewpoint insightfully views Evil Genius as a nightmare that is potentially ceased or finished whenever identified; nevertheless, it does not apply to Evil Genius in Orwell's 1984. In fact, this study contends that Evil Genius in Orwell's 1984 is a nightmare that cannot be overlooked or ceased, as it can manipulate established facts, including mathematics, and can convince people that their beliefs are pointless, thus ironically acquiring people's admiration of its way of deception. This implies that people's ability to think and identify Evil Genius is not a means to challenge it; rather, it is a curse that sometimes impacts humans' consciousness and causes them to indirectly support the devilish vision of the party of Evil Genius, as apparent in Winston's belief that his worst enemy is his own ego.

\section{Discussion}

Orwell's 1984 opens in a gloomy, grey atmosphere that is replete with evilness. It is set in a place where purported utopia turns into a bleak dystopia as "though the sun was shining and the sky a harsh blue, there seemed to be no color in anything, except the posters that were plastered everywhere" (Orwell, 1949, p. 4). It is an inconvenient environment with telescreens everywhere to surveil and control people's own thoughts and beliefs. The party surrounds this shadowy area with all images of Big Brother on "coins, stamps the cover of books, banners, posters and the wrapping 
of a cigarette packet-everywhere" (Orwell, 1949, p. 29), which potentially promulgates the party's different ideologies at the cost of people's consciousness and memory. This atmosphere resembles Descartes' viewpoint of external entities that "are nothing but the bedeviling hoaxes of [humans'] dream, which [Evil Genius] lays snares for [people's] credulity" (1949, p. 107). In support of this, the party hypnotizes people during the Two Minutes Hates and introduces an illusionary enemy, namely Goldstein, to increase people's love of their savior, Big Brother. Like evildoers, the party creates a seamless place for the manipulation of people, which aims at creating a new generation with a deformed conception of evil. Thus, children sometimes function as spies on their parents, monitoring and reporting them to the party.

This doubtful atmosphere of the party is emphasized by Winston, who has a peculiar sense of everything and who raises several doubts about a dark-haired girl, the Brotherhood, and O'Brien. He is not certain of whether O'Brien is a friend or an enemy, considering that O'Brien is viewed as an embodiment of deception for expressing fake feelings regarding his intimacy with Winston. The narrator says,

But there was a fraction of a second when their eye met, and for as long as it took to happen Winston knew-yes, he knew! - that O'Brien was thinking the same thing as himself. An unmistakable message had passed. It was as though their two minds had opened and the thoughts were flowing from one into the other through their eyes. 'I am with you' O'Brien seemed to be saying to him. 'I know precisely what you are feeling. I know all about your contempt, your hatred, your disgust. But don't worry, I am on your side! And then the flash of intelligence was gone, and O'Brien's face was as inscrutable as everybody else's. (Orwell, 1949, p. 19)

O'Brien's evilness, the representative of Evil Genius in 1984, deceives Winston by manipulating his thoughts. He always visits Winston's fantasies in form of flashes that appear in dreams or sober minds. Recurring dreams keep striking Winston's own mind, bringing several doubts regarding his unknown fate. These dreams enable the party to get inside Winston and control or damage his memory. Yet, Winston wrongly fails to realize O'Brien's reality; rather, he views him as an extension of his rebellious thoughts, which causes Winston's soul to get confused. In Descartes's terms, Winston gets to the point of asking: "Are you me? Am I you? If not, who the hell are you? Why do you keep bothering me? There is a reason and must be. There is a reason for everything. I just need to find out what it is. You came uninvited and now that you here I can't see anything but you in front of me. All around me. Inside me. The alien, the monster" (qtd in Klempner, 2015).

The party of Evil Genius potentially dominates Winston's dreams and memory, which constitutes the memory hole through which the party commemorates its own good deeds and disguises the evil ones. This memory hole is a type of space "into which documents deemed conflicting to 'official truths' were placed for disposal, with view to their eventual removal from public consciousness" (Clark, 2007, p. 1). The party works to make people remember only what 
serves its project; therefore, it keeps providing them with delusional memories. Peter Morton (1996) mentions that "the demon has control of your memory, your sensory perceptions, and your faculty of reasoning, so everything that you see, remember, or deduce is simply an illusion the demon creates" (p. 66). Thus, the constant alteration of the past that subsumes "every kind of literature or documentation which might conceivably hold any political or ideological significance" potentially enables the party to achieve its evil-oriented goals (Orwell, 1949, p. 42). This explains why the party in 1984 proclaims the ability to control everything; O'Brien claims that he controls Winston's memory and existence (Orwell, 1949, p. 260).

Yet, Winston "know[s] that the past is falsified, but it would never be possible for [him] to prove it, even when [he] [does] the falsification [himself]. After the thing is done, no evidence ever remains" (Orwell, 1949, p. 162). Whether or not Winston has any piece of evidence against the party's deception, his practice of remembering and thinking allows him to maintain his true existence and unshaken beliefs. He holds the belief that truth lies in his memory; therefore, he attempts to "squeeze out some childhood memory that should tell him whether London [has] always been quite like this" (Orwell, 1949, p. 5). He recalls memories related to his mother and sister, which feeds him with the necessary experience to establish a self-defense mechanism against the party's evil project. Winston thinks that the past does exist in "the records, the mind, the human memories" (Bloom, 2009, p.60), thus asserting that "I remember, therefore I exist" (Orwell, 1949, p. 272).

Trying to control Winston's heavy reliance on his innate ability of thinking and remembering to resist Evil Genius, the party deploys the strategy of "doublethink", which allows certain things to pass through so that everything looks normal. As Orwell (1949) reports, "all that was needed was an unending series of victories over memory. Reality control, they called it in newspeak, doublethink" (p. 37). In "A Metaphysics for the Future", Allinson states that Evil Genius "may choose not to deceive one in every instance and therefore may allow certain moments of genuine cognition to occur" (2017, n.p). To alter history and make its own delusional world less predictable by people like Winston, the party allows Winston to work in the Ministry of Truth. Also, it provides him with Goldstein's book that should help him unearth the past through Mr. Charrington, a thoughtful police member collaborating with the party who decides to conduct the party's project through newspeak, a strategy that entraps people through language.

Considering that Orwell does not believe that moral facts exist independently from language (Tuckerová, 2010, p. 97), the party's evil newspeak is achieved through inventing a language that consists of a new set of vocabulary that drops all types of argument, including the political and ethical. This strategy aims at controlling people's thoughts that might pose a challenge against the party by distracting them from discussing key issues. For example, the party's newly invented language suggests ungood -instead of "evil" or "bad"- as an antonym of good and plusgood-rather than "better"- to indicate excellence (Orwell, 1949, p. 54). Possibly, the 
party is trying to eliminate the word evil from people's dictionary, considering the word's association with the true nature of the party. Syme explains, "don't you see that the whole aim of newspeak is to narrow the range of thought? In the end we shall make thoughtcrime literally impossible, because there will be no words in which to express it. Every concept that can ever be needed will be expressed by exactly one word, with its meaning rigidly defined and all its subsidiary meanings rubbed out and forgotten" (Orwell, 1949, p. 55). The party is trying to create an orthodoxic generation that never considers logical thinking or rational syllogisms, which should result in a very controllable society.

Moreover, the party's newspeak relies on distorting people's knowledge of the past and its association with the present. The heritage of Milton and Shakespeare, for instance, is altered and viewed in opposition to people's beliefs and traditions. Elaborating on this technique, Lytle (2012) writes, "if we doubt the everyday world of solid objects, which is what the evil genius is able to manipulate, then truth lies in our ability to think" of what the party reveals and promotes (p. 88). While this suggests that the party does not prevent people from thinking, it is undeniable that the topics made available for thinking are chiseled and carefully chosen by the party, which represents a phase of doublethink.

As a word of the party's newspeak, doublethink is defined as "to know and not to know, to be conscious of complete truthfulness while telling carefully -constructed lies, to hold simultaneously two opinions which canceled out, knowing them to be contradictory and believing in both of them; to use logic against logic, to repudiate morality while laying claim to it in itself" (Orwell, 1949, p. 37). This genius ideology enables the party to control people's perception of the past and the future, as evident in the scene where a member of the party on telescreens announces that Oceania is at war with Eurasia and in alliance with Eastasia. Although this purported piece of news is broadcasted as the truth that people should adopt and behave accordingly, it is never made final. Everything may change given the party's benefits that view the enemy's state as an "absolute evil", thus making "any past or future agreement with [them] impossible" (Orwell, 1949, p. 36). This behavior reflects Descartes's viewpoint that "to turn falsity to truth and truth to falsity [...] would be the ultimate power. Power to change the past or the future. No more physical power. I'm talking about the power of making any contradiction true just by willing it. It is the power to turn reality into a contradictory truth" (qtd. in Klempner, 2015).

The party does not spare any opportunity to employ the strategy of doublethink to reconstruct what is right or wrong regarding people's beliefs. It utilizes rigid, contradictory slogans all over the place, such as "War is Peace, Freedom is Slavery and, Ignorance is Strength" (Orwell, 1949, p.6). Moreover, it establishes four ministries that are named in a way that contradicts their main missions. The Ministry of Truth is made responsible for producing lies and fabricating news in form of entertainment. The Ministry of Peace is made responsible for waging wars, the Ministry of Love is made responsible for administrating torture, and the Ministry of Plenty concerns itself 
with famines and the shortage of provisions. This strategy causes people to suspect the reality of almost everything, including their moral system and ethics, which causes them to feel that they are always in need for the party to guide and protect them in such a chaotic atmosphere of uncertainty.

Supporting this strategy relying on the principle: "who controls the past [could] control the future: who controls the present controls the past" (Orwell, 1949, p. 37), the party uses telescreens to help its members misguide people. Such telescreens "bruise [their] ears with statics proving that people today had more food, more clothes, better houses, better recreations-that they lived longer, worked shorter hours, were bigger, healthier, stronger, happier, more intelligent, better educated, than the people of fifty years ago" (Orwell, 1949, p. 77). These telescreens enable the party of Evil Genius to control people's "factuality of reasoning" (Morton, 1996, p. 66), hypnotize their conscience, and blur their perception, thus undermining people's ability of thinking and reasoning.

Yet, Winston is not deceived by the party's doublethink or telescreen strategies. He suspects the whole situation thinking that things are not in their "natural order" (Orwell, 1949, p. 63). The propaganda that the party might be right always upsets him, and there always exists a sense of uncertain dates in Oceania, as he observes that "it's impossible to discover the age of anything nowadays" (Orwell, 1949, p. 152). The image of Big Brother raises suspension in Winston's heart. The narrative reports, "the hypnotic eyes gazed into [Winston's]. It was as though some huge force were pressing down upon [him]- something that penetrated inside [his] skull, battering against [him], always to deny the evidence of [his] senses" (Orwell, 1949, p. 83). The image of Big Brother on history books repeatedly reminds Winston of the men who were against the party's philosophy, which implies the party's ability to change the past and deceive people's senses to control people's "sensory perception"(Morton, 1996, p. 66).

Puzzled by this atmosphere, Winston feels uncertain about everything, considering that "the thought of being a lunatic [doesn't] greatly trouble [him]: the horror [is] that he may also be wrong" (Orwell, 1949, p. 83). This feeling leads Winston to the den of Evil Genius, as the party plays another nostalgic trick against him by deploying Charrington to evoke the sense of ancestry and old days of heritage. Winston and Julia rent a room in Charrington's hotel, which allows them to feel the true taste of things. Winston's curiosity leads him to reveal his real intentions before Charrington declaring that he is looking for a piece of truth that may confirm his doubts. He is eager to know whether he and others would have a better life after the revolution., as he believes that the party's history may be correct and that there is no conflicting evidence that suggests the opposite.

Winston reflects again on the party's ideology as well as ability to blind and mislead people. He declares, "The claim of the party to have improved the conditions or human life had got to be accepted, because there did not exist and never again could exist, any standard against 
which it could be tested" (Orwell, 1949, p. 97). The party succeeds in raising Winston's doubts, thus causing him to swing between conflicting thoughts. The party forges the existence and nonexistence of people and their victories and defeats. It creates an imaginary version of someone who can be set as an example that encourages people to view falsehood as a piece of reality. Although Winston knows that there is no Big Brother at all, he does not deny that "a few lines of print and a couple of faked photographs would soon bring him into existence" (Orwell, 1949, p. 49). Likewise, deleting a few lines from here or there may result in deleting the existence of certain individuals. The party executes people who are viewed by the party as a threat against Oceania and its inhabitants; simultaneously, the names of those executed people are always eliminated from records so that people forget them easily.

Winston understands the party's philosophy, ideology, and techniques very well, but he cannot stop it or go against it. Thus, the party deploys another strategy to manipulate those of conscious minds like Winston, Syme, and Julia. The party emphasizes its role in protecting people from external danger, which demands inventing hoaxes of illusionary enemies that may attack people with rocket bombs. Also, the party uses certain agents to uncover the secrets of its opponents. O'Brien, the party's evildoer, is assigned to get closer to Winston and Julia to identify and undermine their doubts about the existence of Goldstein and his conspiracy. O'Brien gives them a book that makes them "learn the true nature of the society they live in, and the strategy by which they shall destroy it" (Orwell, 1949, p. 182). This book does not add new information to Winston, as he already knows that "all the beliefs, habits, emotions, mental attitudes that characterize our time are really designed to sustain the mystique of the party" (Orwell, 1949, p. 219); rather, it satisfies Winston's curiosity and avoids him from carrying out his own investigations.

Moreover, O'Brien attempts to replace Winston's illusionary beliefs or reality with those of the party. He plays the role of the protector and savior of Winston for seven years. One day O'Brien whispers in Winston's ears: "now the turning point has come. I shall save you, I shall make you perfect" (Orwell, 1949, p. 256). O'Brien's gentle voice persuades Winston that he suffers from ineffable memory and that his perception of reality is infected or deluded. Addressing Winston, O'Brien says,

You are mentally deranged. You suffer from a defective memory. You are unable to remember real events, and you persuade yourself that you remember other events which never happened. Fortunately, it is curable. You have never cured yourself of it, because you didn't choose to. There was a small effort of the will that you were not ready to make ... you are clinging to your disease under the impression that it is a virtue (Orwell, 1949, p. 258).

O'Brien "lays snares for [Winston's] credulity" (Descaret, 2000, p. 107) and attempts to falsify the notion of evil in Winston's mind and persuade him of his insanity. 
To this end, O'Brien holds a photograph of three executed men before Winston's eyes, stating that "you believed that you had seen unmistakable documentary evidence that their confessions were false. There was a certain photograph about which you had a hallucination. You believed that you had actually held it in your hands. It was a photograph something like this" (Orwell, 1949, p. 259). O'Brien deploys his cunning and energy to skew Winston's beliefs as hallucinations. He attempts to control Winston's mind and logic, a strategy that reflects the endeavor of Evil Genius to control people's "factuality of reasoning and sensory perception" (Morton, 1996, p. 66). Thus, he informs Winston that the Ministry of love will "cure [him/Winston]! make [him] sane!" (Orwell, 1949, p. 265). O'Brien is trying to indirectly cause Winston to start viewing his thoughts and orientations against the evil party as hallucinations, which should eventually cause other people to start suspecting Winston's viewpoints.

Against the claim that "if we are wary, we need not to be deceived" (Bouwsma, 1949, p. 142), Winston seems influenced by O'Brien's words. He states: "It [is] perfectly possible that O'Brien [has] really forgotten the photograph. And if so, then already he [will] have forgotten his denial of remembering it, and forgotten the act of forgetting" (Orwell, 1949, p. 260). Obviously, Winston's awareness of the party's diction and ideology of doublethink does not save him from questioning his own beliefs, which proves the party's success in shaking Winston's beliefs. Winston interrogates; "how [can] one be sure that it [is] simply trickery? Perhaps that lunatic dislocation in the mind [can] really happen: that [is] the thought that defeats him" (Orwell, 1949, p. 260). It seems that Winston is haunted by suspicion and uncertainty, as thoughts of the party's rightness start to overwhelm him.

Relying on this atmosphere of uncertainty, O'Brien endeavors to persuade Winston that two plus two makes five. Kennington (1971) explains that Evil Genius "would cast everything, including mathematics into doubting", considering that this doubt "is not limited to mathematics but includes the entire class of eternal truths and therefore law of noncontradiction" (p. 444). O'Brien tries to distract Winston from truth, believing that "sensory experience and reason beliefs are certain as long as one is actually attending to their content" (Nadler, 1997, p.46). He sabotages Winston's reason and makes him see five fingers without deformity (Orwell, 1949, p. 270). Then he remarks,

We control matter because we control the mind. Reality is inside the skull. You learn by degrees Winston. There is nothing that we couldn't do. Invisibility, levitation-anything. I could float off this floor like a soap bubble if I wished to. I don't wish to, because the party doesn't wish it. You must get rid of those nineteenth-century ideas about the laws of nature. We make the laws of nature (Orwell, 1949, p. 277).

Against Descartes's principle that deception is limited to language while natural sciences are hard to control (1996, p. 278), O'Brien promotes the philosophical viewpoint of Quine's Evil Genius, 
which suggests that the party can toy with people's perception of natural science through the help of language (French, Uehling Jr., and Wettstein, 1979).

In addition, O'Brien reports that "the earth is as old as we are" (Orwell, 1949, 278) and then asks Winston whether "you suppose it is beyond us to produce a dual system of astronomy? The stars can be near or distant, according as we need them. Do you suppose that mathematicians are unequal to that? Have you forgotten doublethink?" (Orwell, 1949, p. 278). He then exposes Winston, through the soundtrack, to the 'evil' promises he has made in brotherhood. Winston "hear[s] himself promising to lie, to steal, to forge, to murder, to encourage drug-taking and prostitution, to disseminate venereal diseases, to throw vitriol in child's face" (Orwell, 1949, p. 283). Emphasizing such pieces of information, O'Brien "controls [Winston's] memory" (Morton, 1996, p. 66) and proves that the party of Evil Genius "[can] make one think that 2 and 2 is 5 every time 2 [are] to be added to 2 that it should not be beyond the powers of such a malignant being to convince one of a false but seemingly true philosophical argument" (Allinson, 2017, n.p).

The party of Evil Genius "employ[s] all his energies in order to deceive [ Winston]" (Descartes, 1996, p. 19). Consequently, Winston starts thinking whether the earth is flat, ice is thicker than water, or 2 and 2 make 5 in total, which corresponds with his former wonders of "how do we know that two and two make four? Or that the force of gravity works? Or that the past is unchangeable? If both the past and the external world exist only in the mind, and the mind itself is controllable what then?" (Orwell, 1949, p. 84). Now, Winston's perception of reality is different, and his viewpoint regarding the party of Evil Genius should be different as well. Instead of maintaining his belief in reason and feelings to judge things, Winston starts adopting O'Brien's principle that "reality is not external. Reality exists in the human mind, and nowhere else. Not in the individual mind, which can make mistakes and, in any case, soon perishes only in the mind of the party, which is collective and immortal" (Orwell, 1949, p. 261).

The party annihilates Winston's history, as if it has never existed. Thus, O'Brien emphasizes that Winston's worst enemy is his ego, not the party and that clinging to illusionary principles is the prime reason behind people's troubles. Identifying Winston's problems, O'Brien addresses Winston thus,

you are here because you have failed in humility, in self-discipline. You would not make the act of submission which is the price of sanity. You preferred to be lunatic, a minority of one. Only the disciplined mind can see reality. You believed that reality is something objective, external, existing in its own. You also believed that the nature of reality is selfevident. When you delude yourself into thinking you see something, you assume that everyone else sees the same thing as you. (Orwell, 1949, p. 261)

O'Brien attempts to prove that self-deception is worse than getting deceived by others, inviting Winston to abandon his own world in favor of the party's rea/ world. He explains, "your mind 
[Winston] appeals to me. It resembles my own mind except you happen to be insane" (Orwell, 1949, p. 271). O'Brien insists that Winston should fight the demons inside him, confirming that dystopia and iniquities do exist inside the individual, which eventually shatters or demolishes Winston's dream of becoming "the guardian of the human spirit" (Orwell, 1949, p. 284).

\section{Conclusion}

The party of Evil Genius treats Winston as a patient or heretic who needs the Big Brother's help to live healthily and happily. O'Brien explains, "we convert [heretic], we capture his inner mind, we reshape him. We burn all evil and illusion out of him, we bring him over to our side not in appearance, but genuinely heart and soul" (Orwell, 1949, p. 267). Using the strategies of doublethink, forging history and making it a matter of opinion, and promoting evil to protect peacefulness and power, the party reverses truths and convinces Winston that his perception of the outside dystopian world is an illusion. Thus, Winston starts thinking that "stupidity [is] as necessary as intelligence" (Orwell, 1949, p.281). His soul becomes as white as snow while he "walks down the white tiled corridor, with the feeling of walking in sunlight" (Orwell, 1949, p. 311). He renounces all the memories he has had against the world of evil demon, believing that a "spotless mind" brings "eternal sunshine" (Pope, 1835, p. 45), which defrauds his objective perception of reality and truth in favor of the party's perception. The party's logic starts to make sense for him, as he "has been reduced to a horrible shell of his former self [...] he realizes that he truly loves Big Brother" (Alpers, 2003, p. 287).

Interestingly, Winston's process of transformation is not exclusive to the characters of Orwell's 1984. "This drama that [Obrien][has] played out with [Winston] during seven years will be played out over and over again, generation after generation, always in subtler forms" (Orwell, 1949, p. 281). All humans are vulnerable to the deception of Evil Genius, which is present in the many communities of today dystopian world. As Harold Camping (2005) claims, "we could say that the world has officially come into the age of terror. A fictional story of terror now supposes there was someone in the world who was a very, very evil person, and yet, he also had a very brilliant mind. This evil genius sends a message... [as] We see this kind of thinking all over the world today" (p. 2).

\section{Funding Disclosure/Acknowledgement}

There is no funding to acknowledge for this paper. 


\section{References}

Allinson, R. (2017). A Metaphysics for the Future. New York: Routledge.

Alpers, B. (2003). Dictators, Democracy, and American Public Culture: Envisioning the Totalitarian Enemy, 1920-1950. Univ of North Carolina Press.

Bernstein, J. M. (2009). Tragedy. In Richard Eldridge (Ed.), The Oxford Handbook of Philosophy and Literature (pp. 71-94). USA: Oxford University Press.

Bloom, H. (2009). George Orwell's 1984. Infobase Publishing.

Bouwsma, O. K. (1949). Descartes' Evil Genius. The Philosophical Review, 58(2), 141- 151. JSTOR, www.jstor.org/stable/2181388.

Butler, R. (1972). Cartesian Studies. New York: Barnes \& Noble.

Camping, H. (2005). Time Has an End: A Biblical History of the World 11,013 B.C. - 2011 A.D. Vantage Press.

Clark, T. (2007). Stick This in Your Memory Hole. Aduki independent press.

Dearey, M. (2014). Making Sense of Evil: An Interdisciplinary Approach. UK: Palgrave Macmillan.

Descartes, R. (1996). Descartes: Meditations on First Philosophy: With Selections from the Objections and Replies. John Cottingham (Ed.). Cambridge: Cambridge University Press.

Descartes, R. (2000). Descartes: Philosophical Essays and Correspondence. Roger Ariew (Ed.). Hackett Publishing.

"Evil Genius". Oxford English and Spanish Dictionary. Oxford Lexico. https://www.lexico.com/definition/evil genius, accessed 21 May 2021.

French, P. A., Theodore E. Uehling Jr., and Howard K. Wettstein (eds.). (1979). Contemporary Perspectives in the Philosophy of Language. Minnesota: University of Minnesota Press.

Kennington, Richard. (1971). The Finitude of Descartes' Evil Genius. Journal of the History of Ideas, 32(3), 441-446. JSTOR, www.jstor.org/stable/2708359.

Klempener, Geoffery. (2015). Return of the Evil Demon. Youtube. www. youtube. com/ watch? $\mathrm{v}=\mathrm{hUq8CJQfb9M}$, accessed 18 June 2021.

Lytle, Kandace. (2012). Seeing Isn't Believing. In Tracy Lyn Bealer, Rachel Luria, Wayne Yuen (Eds.), Neil Gaiman and Philosophy: Gods Gone Wild! (pp. 85-96). Chicago: Open Court.

Morton, Peter. (1996). A Historical Introduction to the Philosophy of Mind: Readings with Commentary. Broadview Press.

Nadler, Steven. (1997). Descartes' Demon and the Madness of Don Quixote. Journal of the History of Ideas, 58)1), 41-55. JSTOR, www.jstor.org/stable/3653987.

Orwell, George. (1949). Nineteen Eighty Four. York Press.

Pope, Alexander. (1835). The Works of Alexander Pope. A. JVaipy WA. 
Tuckerová, Veronika. (2010). The Totalitarian Languages of Utopia and Dystopia: Fidelius and Havel. In Costica Bradatan and Serguei Alex. Oushakine. (Eds.), In Marx's Shadow: Knowledge, Power, and Intellectuals in Eastern Europe and Russia (95-108). Lexington Books.

Malek J. Zuraikat is an associate professor of English literature and criticism. He teaches several courses of English literature and criticism, including medieval English poetry, in the Department of English at Yarmouk University, Jordan. His main research interest is Middle English poetry, and he has several publications in this field, such as "The Status of Women in the Patriarchal Society of Chaucer's 'The Knight's Tale'", "John Gower's Moral Adaptation of Ovid's 'Tale of Actaeon'", "Questioning the Centrality of the Hero in Beowulf", etc.

Haneen al-Nawasreh is an independent researcher from Yarmouk University. She has a master degree in English literature and criticism, and her main research interest is English literature and culture. 